\title{
TRAJECTORY OF DEVELOPMENT OF INNOVATIVE ACTIVITY OF ENTERPRISES IN THE CONDITIONS OF TRANSFORMATION OF STATE STRATEGIC GOVERNANCE
}

\author{
Los V. O., *Kucherova H.Y. \\ Zaporizhzhia National University \\ Ukraine, 69000, Zaporizhzhia, Zhukovsky str., 66 \\ *Classic Private University \\ Ukraine, 69000, Zaporizhzhia, Zhukovsky str., 70-b \\ vitalos.2704@gmail.com, kucherovahanna@gmail.com \\ ORCID ID 0000-0002-7932-5232, 0000-0002-8635-6758
}

\section{Key words:}

innovation, enterprise, analysis, evaluation, innovation activity, strategic management, strategy.
In the modern economy, innovation is the basis of rapid and stable socio-economic development, which provides a high technological level of the country as a whole and its individual regions. At this stage of Ukraine's economic development, the presence of a certain instability of the economic environment in the country makes it necessary to stimulate innovation activity of all enterprises. Innovative activity is one of the levers of forming the competitiveness of enterprises in the market. The trajectory of development of innovative activity of enterprises in the conditions of transformation of the state strategic management is constructed in the article. The urgency of the topic is due to the transformation of the methodology of state strategic management of innovation and the instability of indicators of innovation activity. In the course of the research of the methods of taxonomic and strategic analyzes, graphic, generalization have been used. The scientific value is the built integral indicator of innovative activity of the enterprises, the characteristic of a trajectory of changes of its components, the substantiation of directions of improvement of strategic management of innovative activity. During the study, the trends of key indicators that characterize the innovative activity of enterprises have been grouped and analyzed. The practical value of the research results is that the path and significance of the formed trajectory of development of innovative activity of enterprises can be used to make strategic management decisions at the level of the state and individual economic entities.

\section{ТРАЕКТОРІЯ РОЗВИТКУ ІННОВАЦІЙНОЇ АКТИВНОСТІ ПІДПРИЕМСТВ В УМОВАХ ТРАНСФОРМАЦІЇ ДЕРЖАВНОГО СТРАТЕГІЧНОГО УПРАВЛІННЯ}

\author{
Лось В.О., *Кучерова Г.Ю. \\ Запорізький національний університет \\ Украӥна, 69000, Запоріжжя, вул. Жуковського, 66 \\ *Класичний приватний університет \\ Україна, 69000, Запоріжжя, вул. Жуковського, 70-б
}

\section{Ключові слова:}

інновація, підприємство, аналіз, оцінювання, інноваційна активність, стратегічне управління, стратегія.
У сучасній економіці інновації $\epsilon$ основою стрімкого та стабільного соціально-економічного розвитку, які забезпечують високий технологічний рівень як країни в цілому, так і окремих ㄲi регіонів. На даному етапі розвитку економіки України наявність певної нестабільності економічного середовища в країні спричиняє необхідність стимулювання інноваційної активності усіх підприємств. Інноваційна активність виступає одним із важелів формування конкурентоспроможності підприємств на ринку. У статті побудовано траєкторію розвитку інноваційної активності підприємств в умовах трансформації державного стратегічного управління. Актуальність теми обумовлена трансформацією методології державного стратегічного управління інноваційної діяльності та нестабільністю показників інноваційної активності. В ході дослідження використано методи таксономічного та стратегічного аналізів, графічний, узагальнення. Наукову цінність становить побудований інтегральний показник інноваційної активності підприємств, характеристика траєкторії змін його складових, обгрунтування напрямів покращення стратегічного управління інноваційною діяльністю. В ході дослідження згруповано та проведено аналіз тенденцій ключових показників, що характеризують інноваційну активність підприємств. Практична цінність результатів дослідження полягає у тому, що шлях та значення сформованої траєкторії розвитку інноваційної активності підприємств можуть бути використані для прийняття стратегічних управлінських рішень на рівні держави та окремих суб'єктів госпоадрювання. 


\section{Statement of the problem}

The issue of strategic management of innovation activity of enterprises is one of the most relevant at the present stage of development of Ukraine's economy, as innovations - technical-technological, organizational, structural - are the basis for competitiveness of the country and individual businesses, a source of competitive advantage. Competitiveness and innovation are concepts that are inseparable from each other in modern conditions of economic development. The lag of Ukrainian enterprises in the innovation sphere from enterprises of other countries does not allow them to ensure a high level of competitiveness and, consequently, sustainable economic development. These circumstances are due to problems that have developed both in the real sector of Ukraine's economy and in the field of scientific and technical development, and relate, in particular, limited methodological tools for strategic management of innovation, low level of cross-sectoral interaction of science, production, education, almost lack of commercialization of scientific developments, etc. In Ukraine, innovation activity is implemented under extremely unfavorable conditions, strategic management at the macro and macro levels is provided with limited funding, as a result we have increased depreciation of fixed assets and production infrastructure, significant reduction of reserve production capacity [1], technological lag, slow digitalization and limited implementation of the concept of smart-specialization in the country. There is a decline in production in knowledge-intensive industries, aging and outflow of highly qualified specialists from the country, insufficient state funding of research, outflow of investments, which hinders the development of innovative activity of enterprises. The crisis in the country exacerbates the situation, which in general necessitates the transition to a knowledge economy at the level of strategic management of innovation activity of enterprises. Resources of extensive growth are exhausted and, in these conditions, to ensure the recovery and prosperity of enterprises it is possible only to introduce the latest technologies and innovations in conditions of limited resources and renewed strategic management, which will extend the cycle of value added of their products and services. The modern concept of strategic management and planning has undergone significant transformations. The present continuity of the conceptual vision of the strategic development of the country in the strategies of previous periods is currently excluded from the content of modern strategic documents and the procedure for their development. The current methodology of strategic management is aimed at correcting the trajectory of innovation activity in the regional, cluster and crosssectoral spaces, taking into account their uniqueness. The multidimensionality of this approach is ensured by the achievement of its goals focused on the development of effective innovation ecosystems, means of implementation and realization of such strategic documents as: Strategy for the development of innovation for the period up to 2030 [2], which aims to build an innovation ecosystem on the basis of a favorable regulatory framework, innovation infrastructure, methodological and consulting support, links of scientists and inventors with foreign companies, increase innovation culture and improving educational activities [2]. This document is reinforced by about 40 developed projects and already approved sectoral strategies, in particular: National Transport Strategy of Ukraine for the period up to 2030, draft Strategy for the development of the industrial complex of Ukraine until 2025, Energy Strategy of Ukraine for the period up to 2030, Basic principles (strategy) of state environmental policy of Ukraine until 2030, National Waste Management Strategy for Ukraine until 2030, the State Strategy for Regional Development until 2021-27 and others. Despite the strong strategic support for the development of innovation in recent years, there is a lack of coherence of strategic documents in cross-functional and crosssectoral interaction of innovation and sectors of the national economy, which limits the full potential of the adopted strategic documents in the future. The use of the full range of strategic tools involved should be oriented towards the formation of a single trajectory of innovative development of an effective ecosystem.

\section{Analysis of recent studies and publications}

Modern research on the strategic support of macroeconomic processes, noted the presence of continuity of the conceptual vision and stereotypes of state strategic decisions, the negative consequences of which are summarized in the work of Kucherova H.Y. [3]. However, in the work of Bugas N.V., Dyakovych Z.R. [8] the prospects of the methodology of strategic management in solving the problems of innovative activity of enterprises are noted. But in practice, the dynamics and structure of key indicators that characterize the state of innovation and innovation activity are unbalanced in time and space. This is confirmed in the results of scientific research of Andryushko A.K. [4], Kasich A.A., Kanunikova K.O. [5], Vinnikova I.I., Marchuk S.V. [6]. However, they do not leave the search for ways to improve innovation in the country, Romanova T.V., Ivanets L.O. [11]. In turn, Fedulova L.I. [9] substantiated the innovative vector of industrial development of Ukraine as a priority sector of the national economy. Some studies of Tkachenko M.O. are devoted to the microinfluence of innovation on the state of the enterprise [11]. The distribution of enterprises according to the criterion of financing innovation activity in the work of Myachyn V.G. and Kutsynska M.V. has been studied [7], where the results show a characteristic unevenness. Noting the significant contribution of scientists, we observe the existing the need for research results in the trajectory of development of innovative activity of enterprises in a reformed system of public strategic management.

\section{Objectives of the article}

The objective of the article is to study the trajectory of development of innovative activity of enterprises in the transformation of state strategic management.

\section{The main material of the research}

The development of the trajectory of development of innovative activity of enterprises is proposed to be carried out by methods of taxonomic analysis, for which 
a set of relevant indicators, the method of their rationing and folding will be selected. The economic content and interpretation of the obtained results will be provided by the results of the analysis of trends in indicators.
Thus, based on the analysis of the scientific literature [12], a system of indicators was formed that characterize the level of innovation activity of the enterprise (Fig. 1).

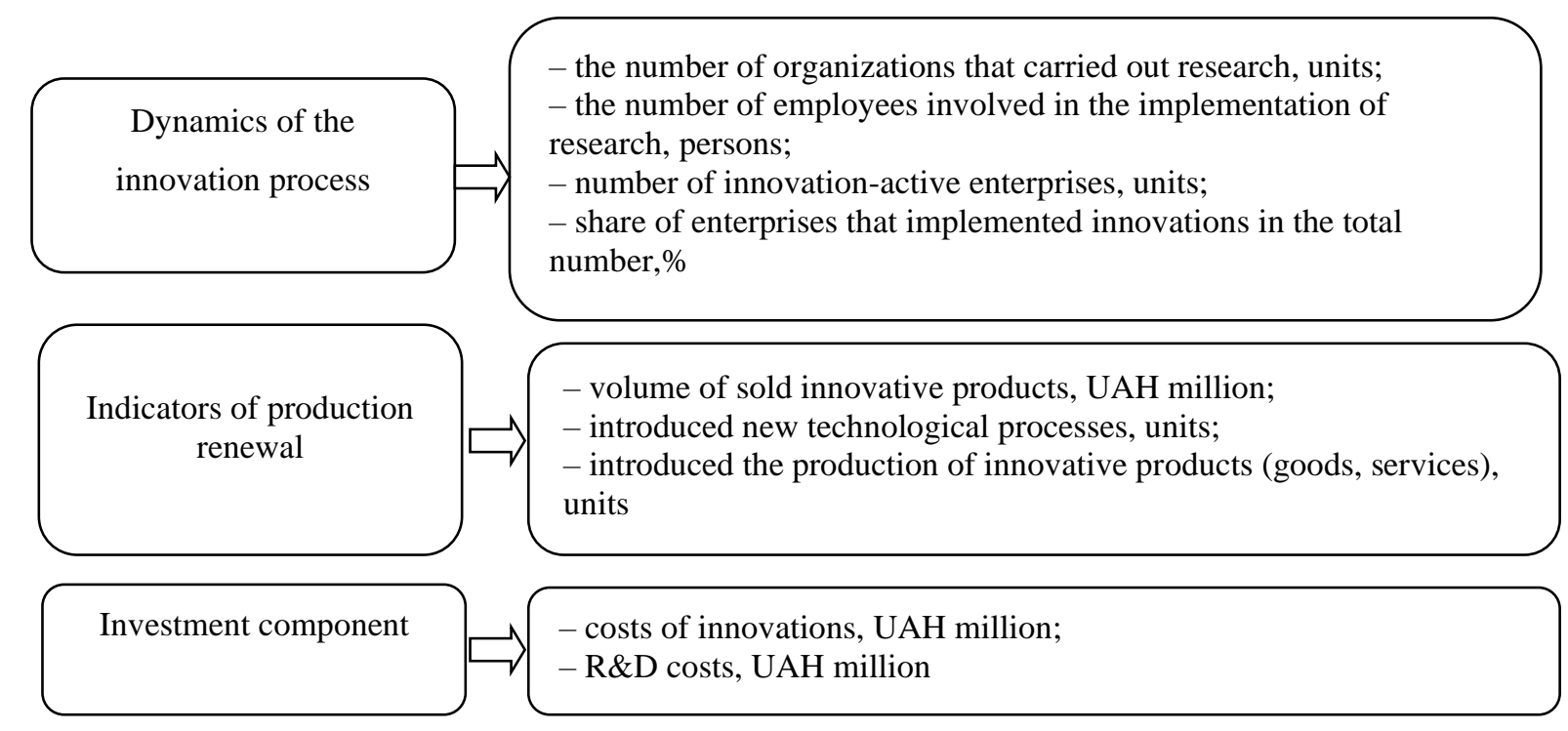

Fig. 1. Indicators of the level of innovation activity of the enterprise

Source: developed by the authors

Let's analyze the dynamics of economic indicators. Thus, for the last twenty years, the maximum amount of funding for innovation is observed in 2016 (Fig. 2). The amount of funding amounted to UAH 23.3 billion, and the growth rate was $64.1 \%$. During the analyzed period, the cost of innovation increased almost eight times. Thus, in 2017, the negative dynamics stopped, but there was no significant increase in innovation costs - the growth rate was $16.8 \%$. And if we compare with 2016, we can see that the cost of innovation decreased by $38.8 \%$. It can also be concluded that the cost of innovation, during the study period,

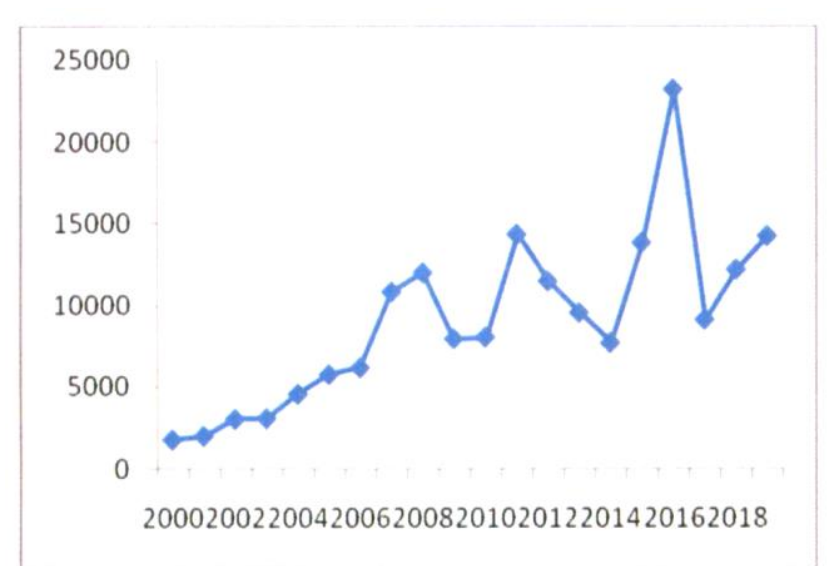

Fig. 2. Dynamics of innovation costs

Source: developed by the authors

Thus, the situation regarding the financing of innovation activity cannot be assessed as positive, because the decrease in the value of this indicator signals a reduction in the volume of innovation activity of enterprises. In addition, significant fluctuations in the ratio of funding sources during the selected study period indicate not only the lack of increased by an average of $19 \%$ annually. Despite the resumption of the level of financing of innovations in 2011, which was accompanied by a sharp increase in total expenditures on innovations $(78.2 \%)$ and thus achieving an absolute figure of UAH 14.3 billion, it is necessary to note a negative steady downward trend in funding innovations during the next 2012-2014. Unfortunately, official statistics for Ukraine are given in current prices, which make it impossible to assess the impact of inflation on innovation expenditures and determine their real value.

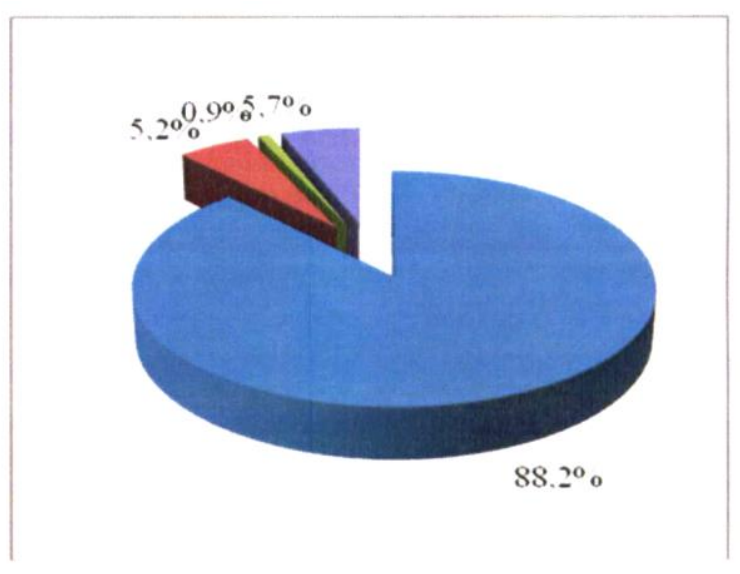

Fig. 3. The structure of innovation costs in 2019 p.

volume, but also the instability of the functioning and reduction of funding sources in Ukraine [13].

The main source of funding for innovation is the own funds of economic entities (Fig. 3), the share of which is $88.2 \%$ of total funding. The share of funding from the state budget is $5.2 \%$, which is $4.8 \%$ more than in 2000 . 
This trend is, of course, positive, but the share of public funding remains meager. In 2019, the share of foreign investors' funds decreased and amounted to about $1 \%$, which is $6.7 \%$ less than in 2000 . This indicates a decrease in Ukraine's investment attractiveness due to hostilities in the east of the country.
In Ukraine, the share of enterprises implementing innovations is very low and averages $15.5 \%$ over 19 years (Fig. 4). In Ukraine, the level of innovation activity of enterprises in comparison with other countries still remains low. Crisis phenomena in the economy have negatively affected the level of innovation activity of Ukrainian enterprises.

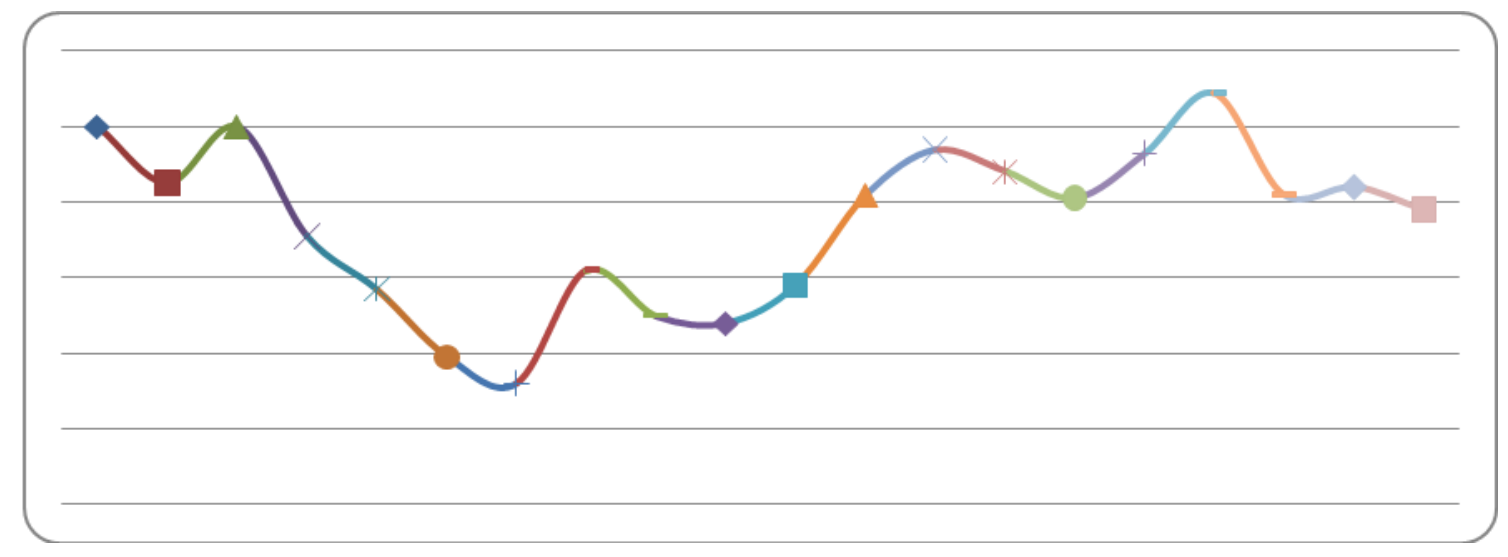

Fig. 4. The share of enterprises engaged in innovation [14]

Source: developed by the authors

From Fig. 4 shows that during the analyzed period the share of innovative enterprises did not exceed $20 \%$. In 2006 , only $11.2 \%$ of enterprises engaged in innovation. In the following years, the share of innovation-active enterprises increased. Thus, in 2019 it was $15.8 \%$, which is $0.6 \%$ less than in 2018. Therefore, despite the fact that innovation is able to increase the efficiency of enterprises and bring them to a qualitatively new level, to ensure capital growth, this process is carried out in practice very slowly.

To determine the trajectory of development of innovative activity of enterprises, we use the method of taxonomic analysis, the stages of which are given in [15]. After performing all the necessary calculations, the values of taxonomic coefficients of the components of innovation activity were obtained, Table 1 .

Table 1 - Taxonomic coefficients of the components of innovation activity of the enterprise

\begin{tabular}{|c|c|c|c|}
\hline Year & $\begin{array}{c}\text { Dynamics of the innovation } \\
\text { process }\end{array}$ & $\begin{array}{c}\text { Indicators of production } \\
\text { renewal }\end{array}$ & Investment component \\
\hline 2011 & 0,626 & 0,565 & 0,444 \\
\hline 2012 & 0,800 & 0,756 & 0,560 \\
\hline 2013 & 0,860 & 0,718 & 0,549 \\
\hline 2014 & 0,792 & 0,603 & 0,539 \\
\hline 2015 & 0,666 & 0,605 & 0,480 \\
\hline 2016 & 0,614 & 0,482 & 0,642 \\
\hline 2017 & 0,591 & 0,722 & 0,762 \\
\hline 2018 & 0,530 & 0,438 & 0,604 \\
\hline 2019 & 0,554 & 0,638 & 0,715 \\
\hline
\end{tabular}

Source: calculated by the authors

The highest value of the taxonomic coefficient of the dynamics of the innovation process is observed in 2012 2014. In this period, the largest number of innovationactive enterprises is observed, which contributed to the highest value of this ratio. The minimum value was recorded in 2017 at the level of 0.53. In 2019, the level of the analyzed indicator corresponds to the average value and is 0.55 . If we compare this value with the previous 2018, we have a slight increase of $4.6 \%$. However, compared to 2011 , the taxonomic ratio of the dynamics of the innovation process decreased by $11.5 \%$. On average, the value of the studied indicator for the period from 2011 to 2019 decreased by $0.7 \%$ annually.
From the table. 1 shows that the values of the taxonomic coefficient of production renewal in 2012 - 2015 and in 2017 and 2019 correspond to a high level. The maximum growth rate was recorded in 2017 and 2019 at $49.9 \%$ and $45.6 \%$, respectively. The current growth rate is due to an increase in the number of implemented technological processes by 2.8 times and an increase in the number of introduced innovative products by 1.09 times. But despite the positive dynamics, the level of renewal of production at enterprises remains very low.

The average value of the taxonomy ratio of the investment component for the study period is 0.59 , which corresponds to the average level. The maximum growth 
rate was recorded in 2016 at $33.9 \%$, which is caused by an increase in innovation spending by 1.8 times. In 2019 , the analyzed taxonomic coefficient is 0.71 , which is $18.3 \%$ more than in 2018. The dynamics of this indicator is growing, but it should be noted that the cost of innovation is very small and in 2019 amounted to only $0.34 \%$ of GDP.

Having calculated the coefficients of taxonomy of all three components of innovation activity, we determine its general level for enterprises using the following formula:

$$
R_{I A}=\sum_{i, j=1}^{n} I_{j} \cdot w_{i}
$$

where $I_{j}$ - the corresponding component of innovation activity (taxonomy ratio); $w_{i}$ - weighting factor of the corresponding component of innovation activity.

To determine the weights, we use the Fishburne method [16]. The weight coefficients of the components of the integrated indicator of the level of innovation activity of enterprises are: The condition is fulfilled: $\sum_{t=1}^{m} w_{i}=0,321+0,317+0,362=1$

Using the obtained weights and group taxonomic coefficients according to formula 1, the level of innovation activity of enterprises was calculated (Fig. 5).

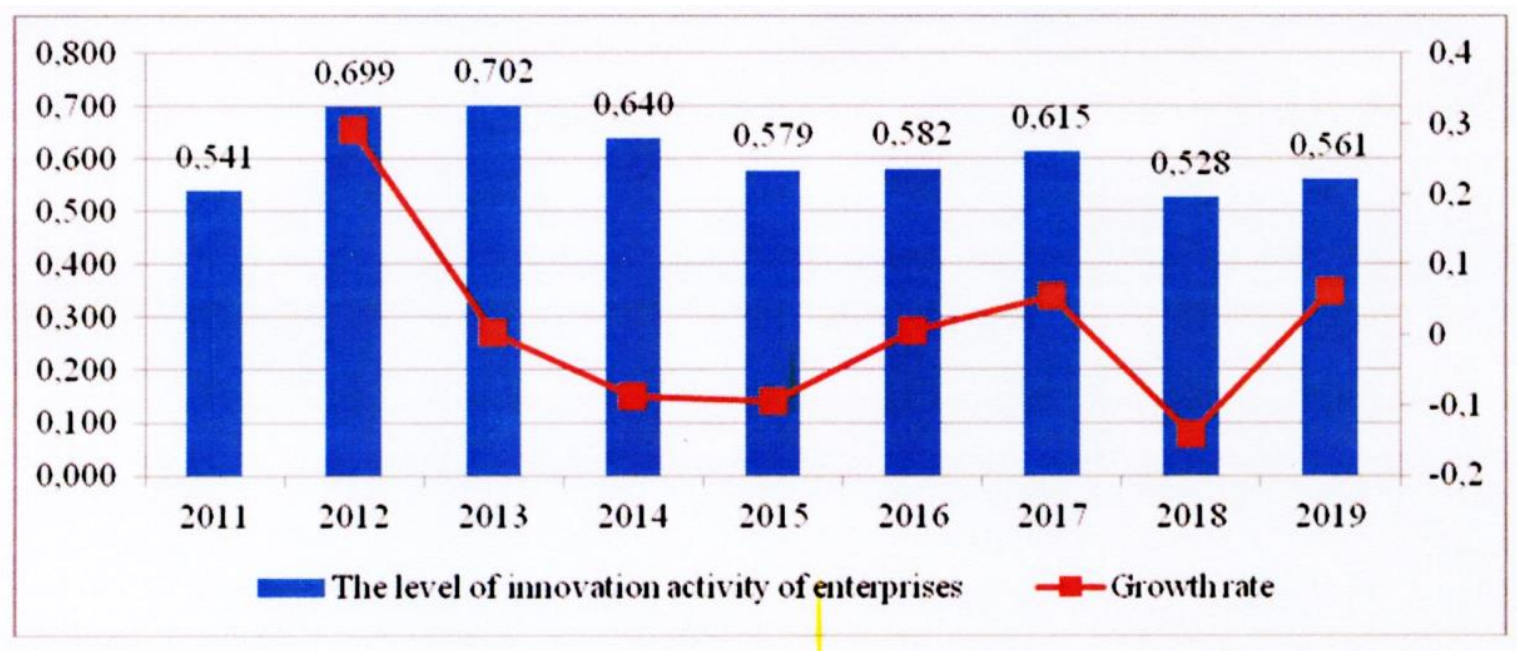

Fig. 5. The trajectory of innovation activity of enterprises

Source: calculated by the authors

Analyzing the dynamics of the integrated indicator, it is clear that the values obtained range from 0.528 (in 2016) to 0.702 (in 2013). In general, during the analyzed period, the average level of innovation activity is 0.605. In 2019, the level of innovation activity compared to 2018 increased by $6.3 \%$ and, compared to 2011 , by only $3.7 \%$. The indicator of the level of innovative activity of enterprises is a relative indicator that characterizes the degree of participation of the enterprise in the implementation of innovative activities over a period of time. Innovative activity characterizes the degree of effectiveness of innovative activities. A qualitative indicator of innovation is the intensity of creation of innovative goods or, in other words, innovation activity, which is measured by the share of innovative products in the gross output of the enterprise, the share of innovative value added in the total value added created by the enterprise.

\section{Conclusions}

The trajectory of development of innovative activity of enterprises of Ukraine, built by methods of taxonomic analysis. During the studied period, the movement of values occurred from the level of 0.541 in 2011 to 0.561 in 2019 , but the way to reach the final value is described by a curvilinear type. Note that the volatility of the integrated indicator of innovation activity is moderate, the coefficient of variation is $10.56 \%$. The dissonance of trends in the components of innovation activity is of concern, in particular, that until 2015, aspects of the spread of the innovation process dominated, i.e. there was a quantitative scaling of innovation growth points. Whereas in the period from 2016 it is dominated by the investment component, due to increased costs for innovation. Indicators of production renewal showed the highest level of volatility in the period under review, which confirms the instability of renewal processes and the inability of the state at the strategic level to stabilize the trend and form an increase in the indicator. Thus, the state strategic management needs to focus on the coherence of trends in the quantitative scaling of innovatively active units, extending the value chain by upgrading products and services and appropriate balancing costs. 


\section{References}

1. Golomb V.V. (2017) Analiz suchasnoho stanu ta problem rozvytku innovatsijnoi diial'nosti u Zaporiz'komu rehioni [Analysis of the current state and problems of innovation development in the Zaporozhye region]. Ekonomika i suspil'stvo - Economy and society, 11, 72-76 [in Ukrainian].

2. Stratehiia rozvytku sfery innovatsijnoi diial'nosti na period do 2030 roku. Rozporiadzhennia KMU vid 10 lypnia 2019 r. № 526-r. [Strategy for the development of innovation in the period up to 2030. Order of the Cabinet of Ministers of July 10, 2019 № 526-r.]. zakon.rada.gov.ua. Retrieved from https://zakon.rada.gov.ua/laws/show/526-2019-\%D1\%80\#Text [in Ukrainian].

3. Kucherova G.Yu. (2015) Mental'na model' derzhavnoho stratehichnoho planuvannia [Mental model of state strategic planning]. Visnyk Odes'koho natsional'noho universytetu imeni I.I. Mechnykova. Seriia "Ekonomika»Bulletin of Odessa National University named after II Мечникова. "Economy" series, 20, 160-165 [in Ukrainian].

4. Andryushko A. K. (2013) Doslidzhennia suchasnoho stanu ta rozvytku innovatsijnoi aktyvnosti pidpryiemstv Ukrainy [Research of the current state and development of innovative activity of Ukrainian enterprises]. Efektyvna Ekonomika - Effective Economy, 3 [in Ukrainian].

5. Kasych A. A., \& Kanunikova K. O. (2016) Innovatsijna aktyvnist' pidpryiemstv Ukrainy: dynamika, problemy ta shliakhy vyrishennia [Innovative activity of enterprises of Ukraine: dynamics, problems and solutions]. Investytsii: praktyka ta dosvid - Investments: practice and experience, 22, 21-24 [in Ukrainian].

6. Vinnikova I. I., \& Marchuk S. V. (2015) Analiz innovatsijnoi aktyvnosti promyslovykh pidpryiemstv Ukrainy [Analysis of innovative activity of industrial enterprises of Ukraine]. Ekonomika ta derzhava - Economy and State, 8, 47-53 [in Ukrainian].

7. Myachyn V. G., \& Kutsynska M. V. (2016) Nejromerezhevyj pidkhid do klasterizatsii haluzej promyslovosti Ukrainy za dzherelamy finansuvannia innovatsijnoi aktyvnosti pidpryiemstv [Neural network approach to clustering of industries of Ukraine by sources of financing the innovative activity of enterprises]. Naukovyj visnyk Khersons'koho derzhavnoho universytetu. Ser.: Ekonomichni nauky - Scientific Bulletin of Kherson State University. Ser .: Economic Sciences, 20(2), 64-68 [in Ukrainian].

8. Bugas N. V., \& Dyakovich Z. R. (2016) Kontseptual'ni zasady stratehichnoho upravlinnia innovatsijnoiu aktyvnistiu pidpryiemstv [Conceptual principles of strategic management of innovation activity of enterprises]. Investytsii: praktyka ta dosvid - Investments: practice and experience, 20, 67-71 [in Ukrainian].

9. Fedulova L. I. (2013) Innovatsijnyj vektor rozvytku promyslovosti Ukrainy. [Innovative vector of industrial development of Ukraine]. Ekonomika Ukrainy -Economy of Ukraine, 4, 15 -23 [in Ukrainian].

10. Tkachenko M. O. (2014) Metodychnyj pidkhid do vyznachennia vplyvu innovatsijnoi aktyvnosti na finansovoekonomichnyj stan pidpryiemstva [Methodical approach to determining the impact of innovation activity on the financial and economic condition of the enterprise]. Komunal'ne hospodarstvo mist. Ser.: Ekonomichni naukyMunicipal Economy. Ser .: Economic Sciences, 115, 98-104 [in Ukrainian].

11. Romanova T. V., \& Ivanets L. O. (2015) Shliakhy pidvyschennia innovatsijnoi aktyvnosti promyslovykh pidpryiemstv Ukrainy [Ways to increase the innovative activity of industrial enterprises of Ukraine]. Efektyvna ekonomika - Effective Economy, 1 [in Ukrainian].

12. Zhits G. I., \& Flegontov A. A. (2009) Ob ynnovatsyonnoj aktyvnosty y faktorakh, opredeliaiuschykh eio uroven' na promyshlennykh predpryiatyiakh. [About innovative activity and the factors determining its level at the industrial enterprises]. Ynnovatsyonnaia deiatel'nost' - Innovative activity, 7, 11-17 [in Ukrainian].

13. Senichkina O. E. (2014) Analiz innovatsijnoi diial'nosti promyslovykh pidpryiemstv Ukrainy [Analysis of innovative activity of industrial enterprises of Ukraine]. DonDUU «Menedzher». Pidpryiemnytstvo, menedzhment, marketynh - DonSU «Manage». Entrepreneurship, management, marketing, 1(67), 109-114 [in Ukrainian].

14. Ofitsijnyj sajt Derzhavnoi sluzhby statystyky Ukrainy [Official site of the State Statistics Service of Ukraine]. ukrstat.gov.ua Retrieved from http://www.ukrstat.gov.ua [in Ukrainian].

15. Sablina N. V., \& Telichko V. A. (2009) Yspol'zovanye metoda taksonomyy dlia analyza vnutrennykh resursov predpryiatyia [Using the method of taxonomy to analyze the internal resources of the enterprise]. Byznes-Ynform - Business Inform, 3, 78-82 [in Ukrainian].

16. Makarova I. L. Analiz metodiv vyznachennia vahovykh koefitsiientiv v interval'nomu pokaznyku suspil'noho zdorov'ia [Analysis of methods for determining weights in the interval indicator of public health]. https://cyberleninka.ru Retrieved from https://cyberleninka.ru/ article/n/analiz-metodov-opredeleniya-vesovyhkoeffitsientov-v-integralnom-pokazatele-obschestvennogo-zdorovya [in Russian]. 